\title{
On morphological radiation of Cladocera (Crustacea)
}

\author{
N.N. Smirnov ${ }^{1}$, A.A. Kotov ${ }^{1,2}$ \\ ${ }^{1}$ Laboratory for Ecology of Aquatic Communities and Invasions, A.N. Severtsov Institute of Ecology \\ and Evolution, Russian Academy of Sciences, Leninsky Prospect 33, Moscow 119071, Russia. E- \\ mails: smirnov08520@mail.ru, alexey-a-kotov@yandex.ru \\ ${ }^{2}$ Laboratory of Paleoclimatology, Kazan Federal University, Kremlevskaya Street 18, Kazan \\ 420000, Russia.
}

ABSTRACT: Our paper is aimed at the development of the idea that morphological radiation precedes adaptive radiation, discussed in earlier studies by Nikolai N. Smirnov with reference to the water fleas (Crustacea: Cladocera).

How to cite this article: Smirnov N.N., Kotov A.A. 2018. On morphological radiation of Cladocera (Crustacea) // Invert. Zool. Vol.15. No.3. P.231-248. doi: 10.15298/invertzool.15.3.03

KEY WORDS: Cladocera, morphology, evolution, adaptive radiationp

\section{О морфологической радиации у Cladocera (Crustacea)}

\author{
Н.Н. Смирнов ${ }^{1}$, А.А. Котов ${ }^{1,2}$
}

\begin{abstract}
${ }^{1}$ Лаборатория экологии водных сообществ и инвазий, Инститкт проблем экологии и эволючии им. А.Н. Северцова РАН, Ленинский проспект 33, Москва 119071, Россия. E-mails: smirnov08520@mail.ru, alexey-a-kotov@yandex.ru

2 Лаборатория палеоклиматологии, Казанский (Приволжский) федеральный университет, ул. Кремлевская 18, Казань 420000, Республика Татарстан, Россия.
\end{abstract}

РЕЗЮМЕ: Данное сообщение развивает идеи о том, что морфологическая радиация предшествует адаптивной радиации, ранее неоднократно высказывавшееся Н.Н. Смирновым применительно к ветвистоусым ракообразным (Crustacea: Cladocera). Как цитировать эту статью: Smirnov N.N., Kotov A.A. 2018. On morphological radiation of Cladocera (Crustacea) // Invert. Zool. Vol.15. No.3. P.231-248. doi: 10.15298/ invertzool.15.3.03

КЛЮЧЕВЫЕ СЛОВА: Cladocera, морфология, эволюция, адаптивная радиация.

\section{Introduction}

Cladocera (Crustacea: Branchiopoda) is a well-known model group in recent studies of evolutionary biology, ecology, physiology, toxicology etc. (Dumont, Negrea, 2002; Lampert, 2011; Smirnov, 2017). Progress in recent biological sciences has resulted in a very strong (sometimes excessive!) specialization of the cladoceran investigators (as well as experts in any other groups of organisms) and prevalence of "modern", "technological" approaches in recent works. Morphology itself is rarely a target of special studies. Usually it is studied by taxonomists only, as part of revisions of groups, or by evolutionary embryologists in "EvoDevo" surveys (Kotov, 2013). But it is obvious that many aspects of "classical" comparative morphology are still superficially studied in the Cladocera (i.e. as compared with mammals or birds), al- 
though this may result from a significant interest to a wider range of zoologists. New data on the morphology of recent and extinct cladocerans have been obtained recently and need a comparative analysis. The latter was partly performed by Kotov (2013) in his recent monograph on the order Anomopoda, and only some questions were answered there.

We can find a lot of valuable observations and generalizations in previous literature concerning the adaptive radiation in the Cladocera (i.e. Smirnov, 1968, 1971, 1999). But even Geoffrey Fryer (Fryer, 1963, 1968, 1974, 1991, 1995), a sequential propagandist of the "adaptationism" explanations of all morphological transformations in the branchiopod crustaceans, wrote that "speciation and adaptation are usually synchronous processes but there are cases when speciation may have preceded adaptive changes" and that "... adaptive changes may have occurred only after the chance events that led to speciation were complete" (Fryer, 1976: 171). He also noted that "large morphological changes cannot then be excluded as agents of evolution", referring to the case of a strange "cyclopic" mutation in Artemia (when a specimen has a single median eye instead of a pair of pedunculate eyes) or duplicated setae on the limbs of Eurycercus (Fryer, 1963). Such "prospective monsters" in the understanding of Goldschmidt (1982) could be the basis for further evolutionary changes. Moreover, many previous authors pointed out that "anomaly" and "norm" have very indistinct boundaries. In reality they demonstrate a continuum created by morphological radiation (Popov, 2000).

Our paper is aimed at the development of the idea that morphological radiation precedes adaptive radiation, earlier discussed several times by Nikolai N. Smirnov with reference to the Cladocera (i.e. see Smirnov, Kotov, 2009, 2010). The terms "adaptive radiation" and "morphological radiation" are usually mixed together in evolutionary literature. Probably this confusion started from Henry Fairfield Osborn (Osborn, 1902), who introduced the term "adaptive radiation". In reality, morphological radiation deals only with the appearance of new forms of organ- isms and their body parts, while adaptive radiation deals with some subsequent events. Vladimir O. Kovalevsky (1875), who proposed the idea of adaptive radiation (named "irradiation" by him), has also discussed cases of "inadaptive evolution" as a result of "precipitate" and "fruitless" progress. The ideas of V.O. Kovalevsky formulated at the end of the 19th century could not be regarded "naïve", even in the beginning of the 21 st century.

Together with recent forms, we have analyzed all the data on fossil cladocerans obtained to date. Although each fossil record is still a relatively rare event for the Cladocera, using such information in our discussion is useful for understanding of the time ranges of morphological evolution both of the Cladocera in toto and its separate macrotaxa.

\section{Results and Discussion}

Morphological radiation takes place based on a vaguely large number of specimens and during a vaguely long time. It has resulted in both useful and useless forms, and even abnormalities (Meyen, 1987). Analyzing the latter is important to understand that "anomaly and norm are characteristics of separate traits, but not whole organism" (Popov, 2000). We like the ideas of Takhtajan (1983) that evolutionary transformation is possible by means of a "polish" of the "monsters" by natural selection and the point of view of Rasnitsyn (2008) that "epigenetic theory regards aberrations as a material for natural selection, the latter is able to create a new adaptive form based on the former". To our minds such conclusions confirm that morphological radiation precedes adaptive radiation.

Cases of different abnormalities in Cladocera are intensively discussed by previous authors (see review in: Kotov, 2013). Sometimes morphologically anomalous forms are relatively frequently present in populations. One of such anomalous morphotypes of the usual chydorid Disparalona rostrata (Koch, 1841) was described as a separate genus Phrixura P.E. Müller, 1867 (see Fryer, 1997). The most spectacular 

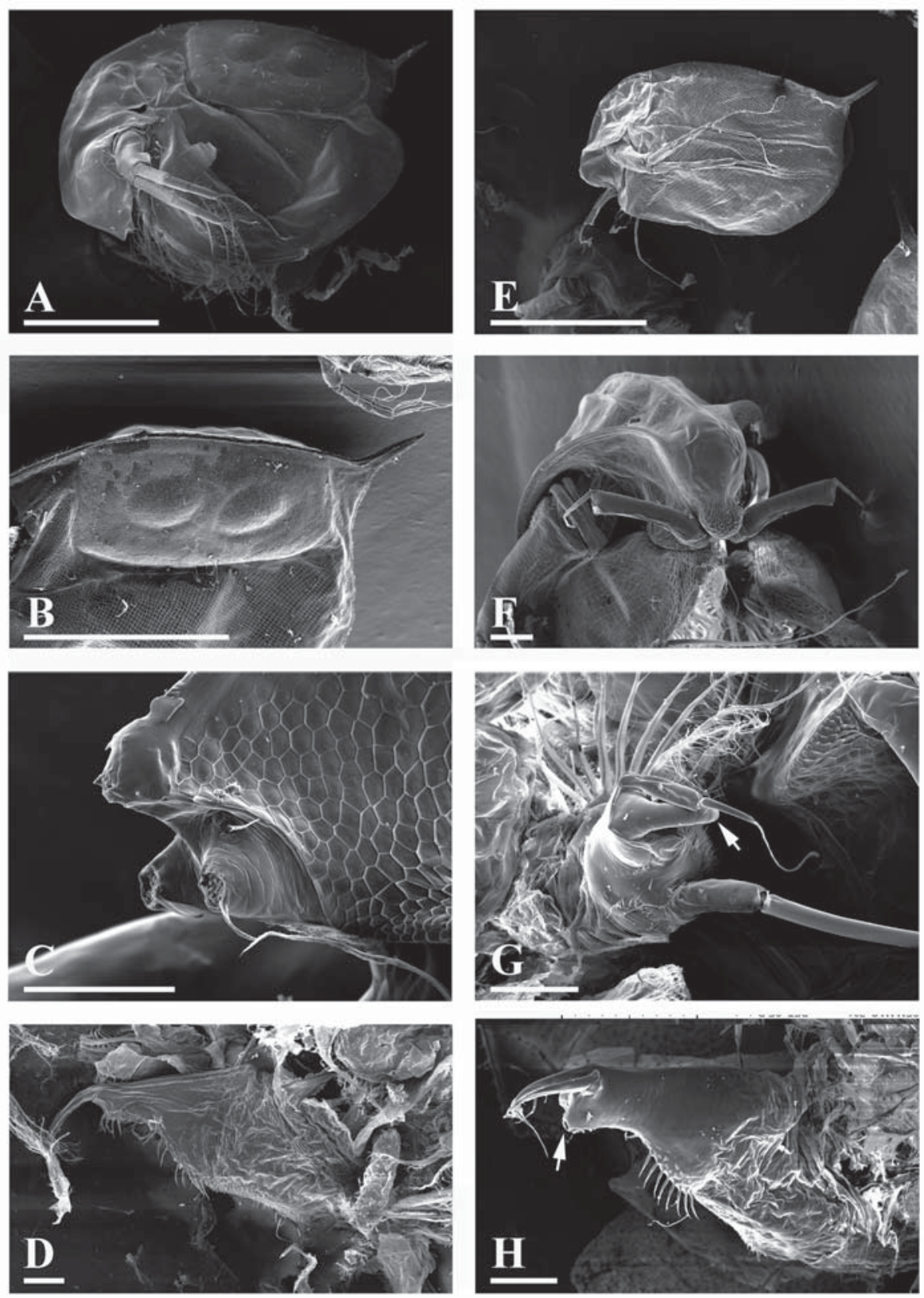

Fig. 1. Normal gamogenetic specimens of Daphnia (Ctenodaphnia) magna. A — ephippial female; B ephippium, C - rostral portion of head, see very short antennae I; D - postabdomen; E - adult male; F anterior view, see long antennae I; G - limb I with copulatory hook (arrow); H - postabdomen, see projected gonopore and reduced postanal teeth (arrow). Scale bars $1 \mathrm{~mm}$ for A-B, E; $0.1 \mathrm{~mm}$ for C-D, E-H. Рис. 1. Нормальные гамогенетические особи Daphnia (Ctenodaphnia) magna. А - эфиппиальная самка; В - эфиппиум, С - ростральная часть головы, см. очень короткие антенны I; D постабдомен; Е - взрослый самец; F — вид спереди, см. длинные антенны I; G - торакопод I с копуляторным крюком (стрелка); $\mathrm{H}$ - постабдомен, см. гонопор на специальном возвышении и редуцированные постанальные зубцы (стрелка). Масштаб: 1 мм для A-B, E; 0,1 мм для C-D, E-H. 
are gynandromorphs, combining traits of two sexes (Figs 1-2). Their frequent records could be regarded as a sign of incompleteness of the sexual difference formation in the cladocerans. Similar conclusions were made by the geneticists (Reisser et al., 2017) who found that at least in Daphnia magna we can recently see a transition from environmental to genetic sex determination (i.e. formation of female heterozygocity with a $\mathrm{W}$-chromosome). This species may produce maleless clones, and this is a norm, not an anomaly, for D. magna Straus, 1820 (Galimov et al., 2011).

Adaptive radiation is a process of adaptation to particular environmental conditions which could be changed significantly with time. Strongly specialized representatives of any group (reached a limit in morphological changes of separate organs, a "culmination" in terms of Kovalevsky, 1875) are well-adapted to their life in particular conditions. But they are unable to adapt to a radical change of their life style and, as a result of environment changes, turn out to be in unfavorable conditions. Smirnov (1999) named them "victims of morphological radiation".

The pace of morphological radiation could change from rapid to very slow, or even to a full stop, the latter situation is named "morphological stasis" and is known in many organisms (Charlesworth, Lande, 1982; Sturmbauer, Meyer, 1992). Morphological stasis is probably characteristic of different groups in the Cladocera (Frey, 1982, 1987), similarly to another branchiopod crustaceans - tadpole shrimps (order Notostraca). Although the opinion on their permanence in fine morphological details during the last millions of years (Trusheim, 1938; Longhurst, 1955; Tasch, 1969) is inaccurate (Mathers et al., 2013; Wagner et al., 2017), we need to conclude that their morphology changed little since the Palaeozoic, and the notostracans are in a deep morphological stasis since that time.

A controversial situation is observed only in few cladoceran taxa, for example, European Bosmina (Eubosmina) Seligo, 1900 (Faustová et al., 2010; 2011). In the Pleistocene these animals were morphologically uniform and more recently (roughly, from Pleistocene/Holocene boundary) they demonstrated a rapid morphological evolution which resulted in many morphotypes (Fig. 3). Such change from stasis to explosive evolution agrees well with the model of a transition from a coherent to non-coherent evolution by Krassilov (1986), or by the model of punctuated equilibrium of Eldredge and Gould (Eldredge, Gould, 1972; Gould, Eldredge, 1977). In contrast, morphological evolution in the majority of cladocerans followed a coherent scenario at least during the whole Pleistocene and Holocene (Frey, 1987). At the same time, abiotic factors changed strongly and repeatedly during that time, at least in the context of global and regional temperature and moisture. Most probably, mass extinctions were consequences of such changes (i.e. by thermophilous taxa in high latitudes) instead of morphological adaptations.

Morphological speciation is considered extremely slow in the cladocerans, it takes millions of years as a minimum (Frey, 1987). But the Cladocera is a very old group which passed through different periods of radical changes of the aquatic environment and biocoenotic crises (Van Damme, Kotov, 2016). Reaction to such changes according to the "adaptationist" logic must be more operative due to a strong chance otherwise to become extinct. Mass extinctions apparently took place in cladoceran history (Korovchinsky, 2006). Usually such extinctions are followed by periods of a rapid diversification (Rasnitsyn, 1987), but we have no information on such events in cladoceran history to date, this is a task for further studies.

Earlier it was proposed that proto-cladocerans had a relatively large size and their diminishing is a result of a strong pressure from planktivorous fishes to large-sized invertebrates (Kerfoot, Lunch, 1987). But our analysis of palaeontological data demonstrate that during at least last 150 millions of years the maximum size of cladocerans did not reduce. The size of all fossil cladocerans found to date is within the range of recent taxa. Moreover, there were many small-sized representatives (less than $1 \mathrm{~mm}$ in length) among Mesozoic cladocerans (Kotov, 

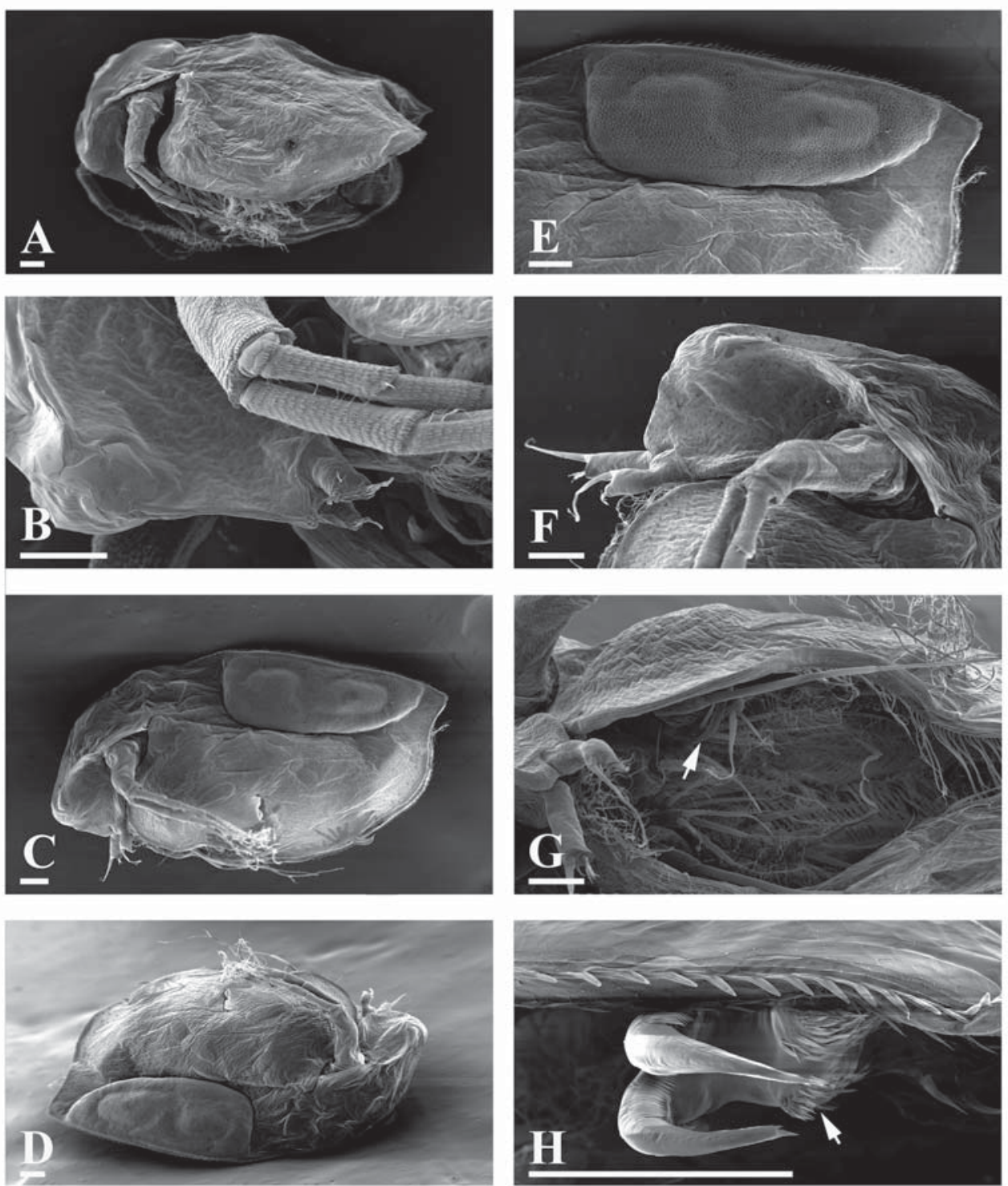

Fig. 2. Two gynandromorph specimens of Daphnia (Ctenodaphnia) magna. A-B - female with elongated antennae I; C-D - "ephippial male", with a combination of characters of ephippial female and male, lateral and dorso-lateral view; E - its ephippium with somewhat unusually developed egg loci; F - head, see moderately elongated antenna I; G - ventral view, copulatory hook developed on left limb I (arrow), but absent on right limb I; H - postabdomen with close gonopores (arrow) and atypical, numerous and small postanal teeth. Scale bars $0.1 \mathrm{~mm}$.

Рис. 2. Две гинандроморфные особи Daphnia (Ctenodaphnia) magna. A-B - самка с необычно длинными антеннами I; C-D - “эфиппиальный самец”, сочетающий признаки эфиппиальной самки и взрослого самца, вид сбоку и дорсо-латерально; Е- эфиппиум этой особи с несколько недоразвитыми яйцевыми камерами; F — голова, см. антенны I средней длины; G — вид с вентральной стороны, см. копуляторный крюк на левом торакоподе I (стрелка), но таковой отсутствует на правом торакоподе I; H - постабдомен с закрытыми гонопорами (стрелка) и атипичными многочисленными и мелкоразмерными постанальными зубцами. Масштаб: 0,1 мм. 

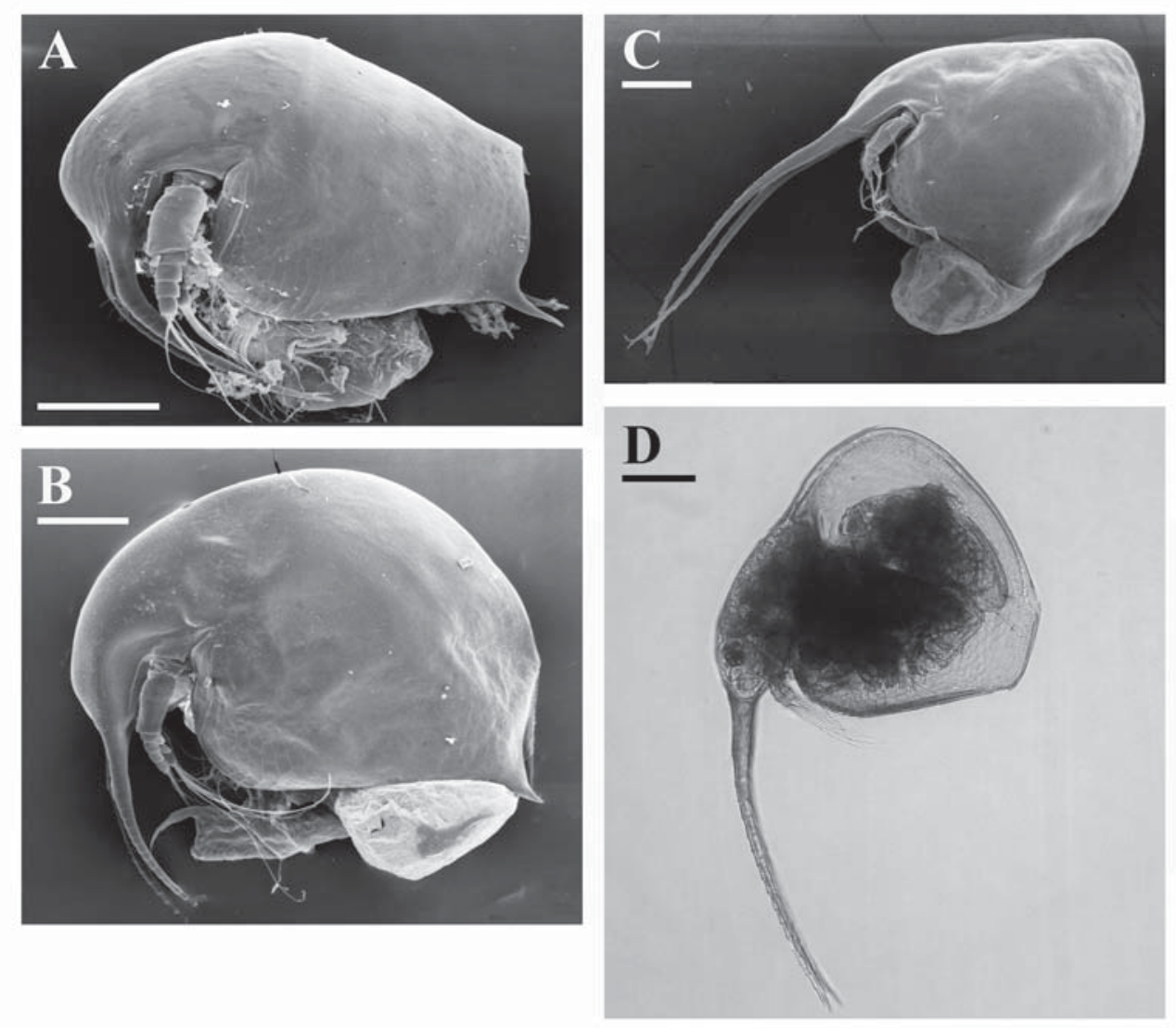

Fig. 3. Ancestral (A) and derived (B-D) morphotypes of European Bosmina (Eubosmina). A - Bosmina coregoni $\mathrm{cf}$. longispina; B - Bosmina coregoni $\mathrm{cf}$. kessleri; C-D - Bosmina coregoni $\mathrm{cf}$. thersites. Scale bars $0.1 \mathrm{~mm}$.

Рис. 3. Анцестральный (А) и производные (B-D) морфотипы европейских Bosmina (Eubosmina). АBosmina coregoni cf. longispina; B - Bosmina coregoni cf. kessleri; C-D - Bosmina coregoni cf. thersites. Масштаб: 0,1 мм.

2007; Van Damme, Kotov, 2016). Here we need to take into consideration that the diversity of small-sized fossil forms is usually underestimated when compared with large-sized forms, not vice versa (Cooper et al., 2006). To date we do not have any evidence of size diminishing in cladoceran evolutionary history. Indeed, there are some genera with specially small size (e.g. Alonella Sars, 1862). Strong reduction of body size took place in only a few taxa from the group independently in different families, while size of the majority of taxa did not change during all cladoceran evolutionary history. For example, there are no differences in size between ephippia of several Mesozoic taxa (Smirnov, 1992; Kotov, Taylor, 2011; Hegna et al., 2016) and recent taxa (Fig. 4).

Small size is characteristic of the cladoceran sister group, the order Cyclestherida. The latter form a monophyletic clade together with the cladocerans, the Cladoceromorpha (Ax, 1999; Kotov, 2013). Cladoceromorphs are initially differentiated as a small-sized group of the crustaceans. Their body size is a product of morphological radiation in the Branchiopoda which apparently preceded adaptation to the 

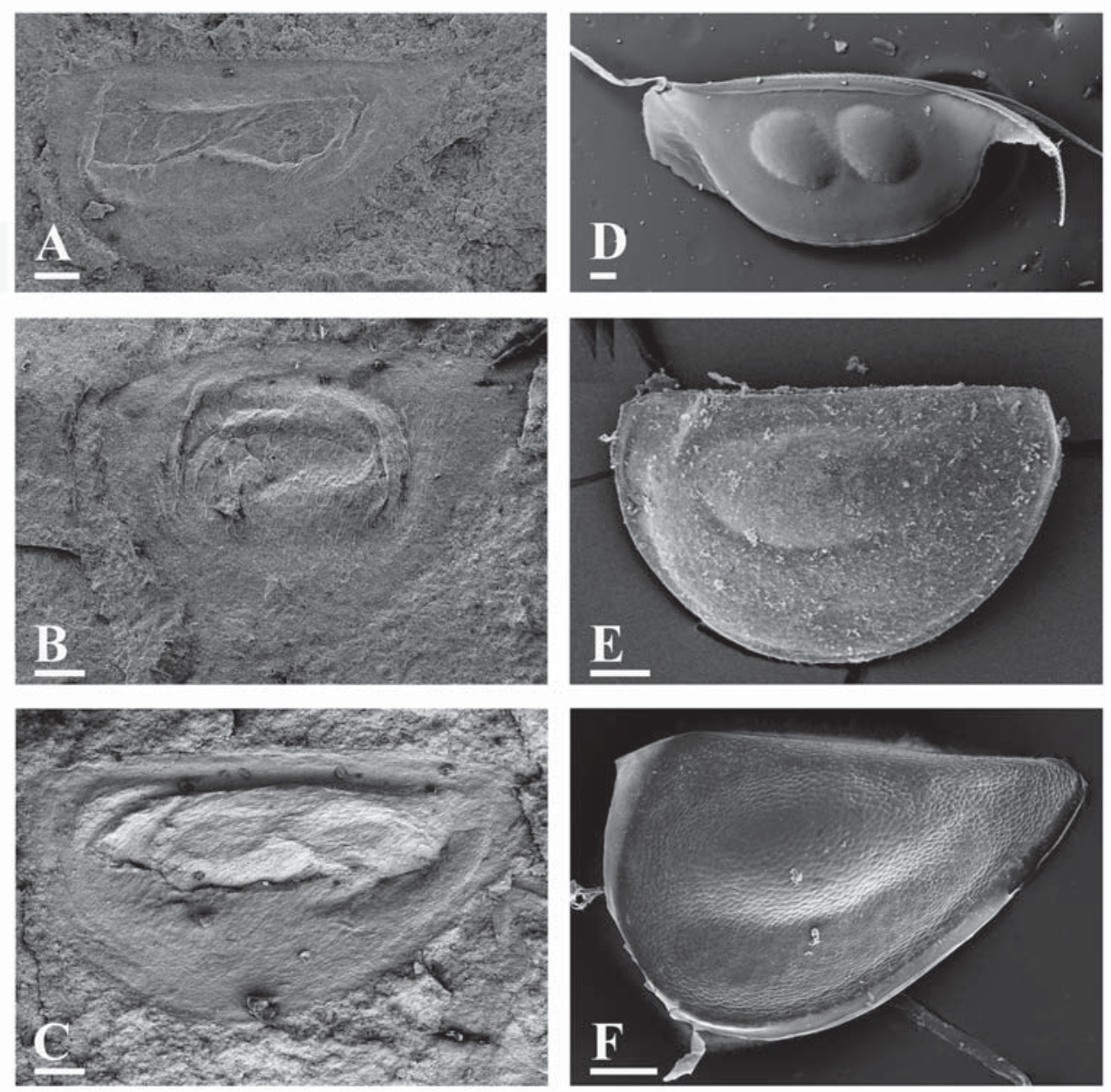

Fig. 4. Fossil ephippia from Khotont, J/C boundary, about 145 MYA (left) and recent (right) ephippia of the Daphniidae (Cladocera: Anomopoda). A - Daphnia (Ctenodaphnia) sp., B - Ceriodaphnia sp.; C Simocephalus sp.; D - Daphnia (Ctenodaphnia) similis, Israel; E - Ceriodaphnia sp., Tasmania; F Simocephalus cf. vetulus, Republic of South Africa. Scale bars $0.1 \mathrm{~mm}$.

Рис. 4. Эфиппиумы ископаемых Daphniidae их Хотонта, граница юры и мела, около 145 млн.л.н. (слева) и современные (справа) эфиппиумы Daphniidae (Cladocera: Anomopoda). A — Daphnia (Ctenodaphnia) sp., B - Ceriodaphnia sp.; C - Simocephalus sp.; D - Daphnia (Ctenodaphnia) similis, Израиль; E - Ceriodaphnia sp., Тасмания; F — Simocephalus cf. vetulus, ЮАР. Масштаб: 0,1 мм.

environment of continental water bodies of "recent" type. Continental water bodies in the Palaeozoic had an appearance which was absolutely different from recent ones (Ponomarenko, 2012; Van Damme, Kotov, 2016). Subsequently, small size - a cladoceran trait since the Palaeozoic stage of their evolution - became to be very helpful for adaptation in the zone of macro- phytes, which was formed in its recent appearance only in the Caenozoic, and for survival in the plankton under a strong pressure of smallsized planktivorous fishes which were absent in Palaeozoic and earlier Mesozoic (Van Damme, Kotov, 2016). Adaptation to recent conditions took place after at least hundred millions of years after appearance of the cladoceran body 
plan. The latter was a product of morphological radiation of the branchiopod macrotaxa, which led to separation of the cladoceromorphs as a distinct evolutionary lineage. Therefore, the cladoceran body plan was a basis for subsequent morpological changes in frames of a subsequent adaptive radiation of this group.

Adamowicz and Sacherová (2006) mathematically tested the hypothesis that the evolution of the appendages in Chydoridae - the most diverse family of the cladocerans - passed predominantly through loss of some elements of morphological rows, mainly setae ("evolution via loss"), which is correlated with the size reduction in several genera of Chydoridae. They called such modifications "oligomerization", although such use of this term contradicts to its understanding by Dogiel (1954) and its followers (Smirnov, 1969, 1971). Also it is necessary to take into consideration some obvious mistakes in their matrix (Kotov, 2013; Sinev, 2017). But we believe that the main conclusion of Adamowicz and Sacherova (2006) that such modifications took place many times, and independently, and there are no signs that the "evolution via loss" has adaptive meaning, is correct. Moreover, a version that such modifications took place due to a morphological radiation, and already subsequently were useful in the frame of adaptive radiation seems preferable to us. "Evolution via loss" took place both in non-related genera that inhabited very different ecological niches, and in close relatives within the family Chydoridae, which inhabit similar niches.

We did not see any evidence of an adaptive meaning of oligomerization itself(sensu Dogiel, 1954). Moreover, oligomerization is a complex of correlated or non-correlated evolutionary morphological transformations of different systems of organs and in very different situations. Each such modification could be used in some ecological situation, but others, in contrast, could even cause difficulties for an organism changing its mode of life. For example, the bosminids apparently have originated from chydorid-like ancestors (Woltereck, 1919) with strongly oligomerized rows of setae on their thoracic limbs as compared with an ancestral state for the
Cladocera (Kotov, 2013). Such “chydorid" state of the bosminid limbs caused serious limitations for their feeding: it determines the consuming by bosminids of larger particles and the impossibility to use smaller particles (small-sized algae, bacteria) in the plankton. At the same time, the daphniids with non-oligomerized setal rows are able to consume smaller particles (Kotov, 2013) which allows them to win in a competition against bosminids under certain conditions. The competitive outcome between Daphnia O.F. Müller, 1875 and Bosmina Baird, 1845 depends on the conditions, but under non-cyanobacterial and low predation pressure conditions Daphnia wins. However this is an example where there are adaptations that compensate other adaptations: limbs in Bosmina were not primarily built for pelagic feeding - but Bosmina competes due to other adaptations. The result of competition in this pair of genera depends on the conditions in each water body, but just the daphiids usually dominate in the plankton of majority of the water bodies in temperate latitudes.

"Molecular clock" estimations led to a conclusion on a mid-Palaeozoic differentiation of the subfamilies within the family Chydoridae and on earlier Mesozoic differentiation of the genera within the family Daphniidae (Lehman et al., 1995; Sacherová, Hebert, 2003). At that time, no plankton and no littoral zone in their recent appearance existed (although, of course, a water column and a substratum existed in such water bodies). Most Mesozoic water bodies had no recent analogues (Zherikhin, 2003; Ponomarenko, 2012). But just at that time a general plan of the Daphniidae (as a future zooplankter) and of the Chydoridae (future inhabitant of littoral zone) was formed. The body plans of a plankter and a littoral inhabitant have appeared already in the Mesozoic, before the appearance of the biotopes where they occur now. The Mesozoic water bodies had only precursors analogues of these biotopes (i.e. littoral zone with Chara and floating algal mats vs pelagic). Formation of the aforementioned body plans (with a series of valuable morphological characters) and «life forms» could not be explained by 
adaptive radiation. At least at earlier stages of their evolution, such animals could be adapted to absolutely different conditions in the water bodies (which are not studied well).

Morphological stasis took place not only in the absence of evolution of the general cladoceran body plan, but also in their separate groups. A most spectacular example is Ctenopoda, for which we know several remarkable fossil Mesozoic representatives. Their body plan has not changed during the last 175 million years (Kotov, Korovchinsky, 2006; Kotov, 2007) (Fig. 5). At the same time, relatively uniform body organization did not cause difficulties in a significant adaptive radiation in the ctenopods, occupying quite different ecological niches in recent water bodies. Many of them are extremely fast planktonic forms, others belong to phytophilous complexes with different styles of life, from bottom dwellers to specialized forms living attached to floating leaves of macrophytes (Korovchinsky, 1990, 2004). Their swimming antennae (= antennae II) have different sets of segments and setae, but their body plan also existed since the Earlier Jurassic (Kotov, 2007). Therefore, adaptive radiations of the antennae II, as the main organ of locomotion, was based on the antique body plan.

No extensive paleontological records of Mesozoic and Palaeozoic cladocerans exist, but we can assume that all highly adapted representatives living in these eras mostly have gone extinct during the formation of "recent" appearance of the water bodies. They became "victims of adaptive radiation", although many other factors influenced changes of the cladoceran fauna also. Forms appeared as a result of morphological radiation and were confronted by an aggressive environment, and just this confrontation caused adaptive radiation. It is important that highly specialized forms are usually living in restricted biotopes (Camptocercus Baird, 1834) and never demonstrate high density in these water bodies (Smirnov, 1999). Such inhabitance in local biotopes in the water bodies could be confirmed by the data of historical ecology: chitinous fragments of such species are never ample in the bottom sediments (see numerous examples in the monograph of Smirnov (2010)). But it is necessary to add that some taxa having no such extreme morphological adaptations are also very rare (i.e. Ovalona karelica (Stenroos, 1897), Pleuroxus pigroides Lilljeborg, 1901, see Smirnov, 2004; Van Damme et al., 2011).

Among the cladocerans and in the current understanding of the taxa, there are a few genera rich of species (Daphnia, Alona, Macrothrix, Bosmina, Chydorus) and many genera contain just a few species (Fig. 6). Existence of the latter may be explained both by their morphological stasis, and by the elimination of intermediate forms that appeared as a result of morphological radiation. But it is necessary to take into consideration that a discussion of such questions is quite difficult: the result depends greatly on a "style" in the taxonomy of different groups, i.e. recent tendency to excessive, crude "splitting" in some cladoceran taxa (Kotov, 2013), first of all, the "Alona-like" species (see the list in Van Damme et al., 2010). As a result we have to date numerous Alona-like genera with minute differences, which are apparently less expressed that differences, for instance, between some species groups in the genus Daphnia or Moina (see Alonso, 1996). In addition, this splitting is not confirmed by an adequate phylogenetic reconstruction, only a very preliminary, draft view of the relationships between certain groups exist (Van Damme, 2010; Sinev, 2017).

Within some genera of cladocerans the species are well-differentiated based on morphological characters (Frey, 1988; Smirnov et al., 2006). But within other genera such differences are minute or even fully absent among the parthenogenetic females (Belyaeva, Taylor, 2009; Popova et al., 2016). Frey (1976: 2212) noted about the remains in the sediments: "The chydorids constitute a taxocene of closely related species occupying the same macrospace". Such formation of numerous species, almost indiscernible morphologically and with very unclear adaptive advantages (at least for the cladocerans) could be a result of a morphological radiation. Based on "adaptationism", it is difficult to explain the formation in sympatric conditions of 

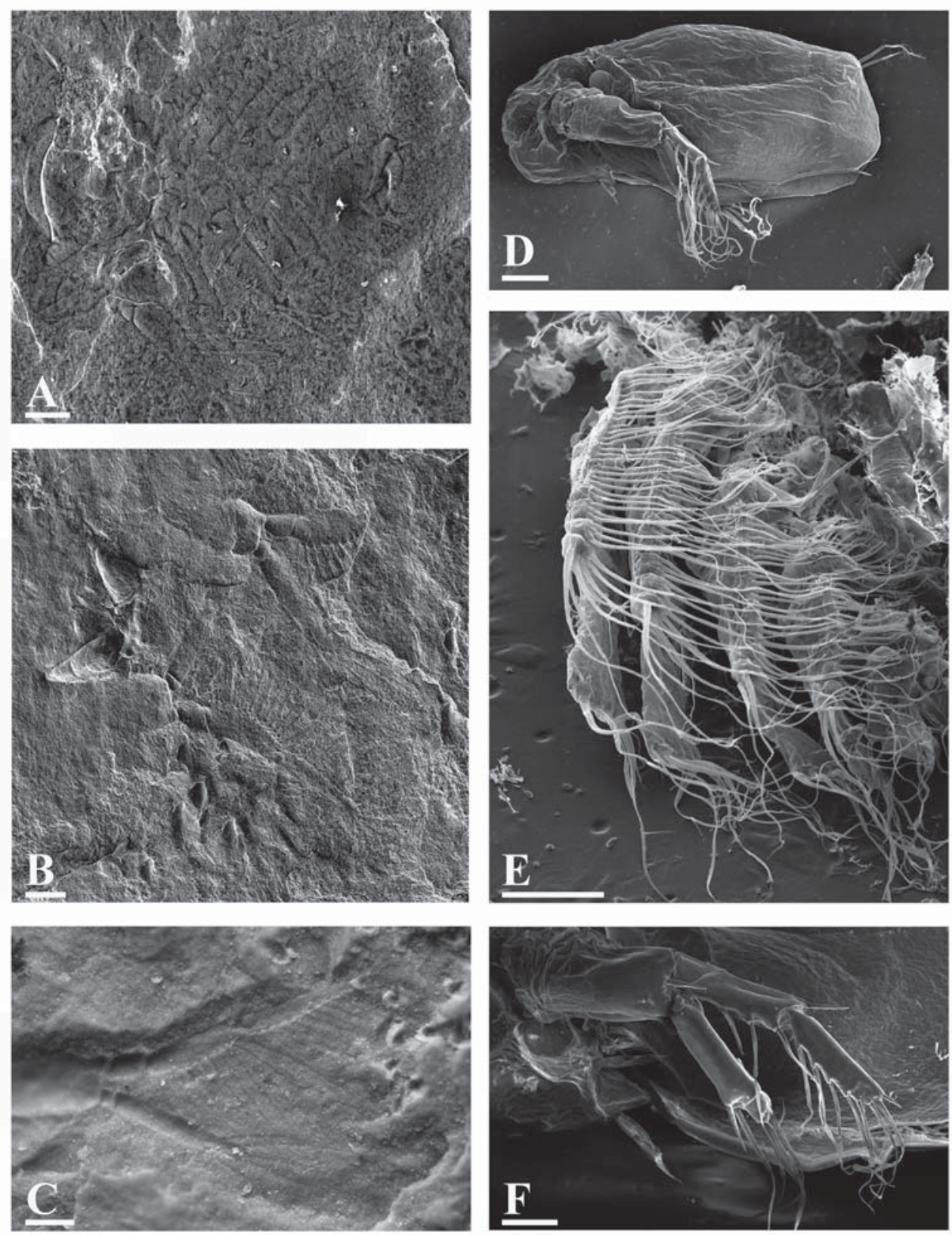

Fig. 5. Fossil representatives of Sididae (Cladocera: Ctenopoda) from Ust'-Baley, Earlier Jurassic, about 175 MYA (left, A-C) and recent Sididae (right, D-F). A - Smirnovidaphnia smirnovi, ventral view; B anterior body portion with well-preserved antenna II and mandibles; C — antenna II; D - Sida crystallina, lateral view; E - thoracic limbs; F - antenna II. Scale bars $0.1 \mathrm{~mm}$.

Рис. 5. Ископаемые представители семейства (Cladocera: Ctenopoda) из Усть-Балея, ранняя юра, около 175 млн.л.н. (слева, А-C) и современные Sididae (справа, D-F). А — Smirnovidaphnia smirnovi, вид с вентральной стороны; В - передняя часть тела с хорошо сохранившимися антеннами II и мандибулами; C - антенна II; D — Sida crystallina, вид сбоку; E — торакоподы; F — антенна II. Масштаб: 0,1 мм. 
several species of pelagic Daphna with minimal differences in their morphology. Moreover, it is known that the general body shape in pelagic daphniids varies among water bodies, but different species frequently have a similar shape in a single water body (Glagolev, 1986). Another example of a large cluster of morphologically similar taxa are "Alona-like chydorids" (see discussion in Smirnov, Kotov, 2009). Their body shapes is discussed by Van Damme (2010) in his Ph.D. Thesis, i.e. (1) explanation of some shapes by adaptation to hydrodynamic pressures, and (2) the separation of evolution of the body plan versus the limbs, for example in Nicsmirnovius (tapered shape which is better for flow).

In case of gamogenetic specimens, even "minute" morphological differences could have a very serious significance for a reproductive isolation between congeners, for example, for recognition of females by the male during copulation (Smirnov, 1971; Van Damme, Dumont, 2006). But it is difficult to explain minimal differences between parthenogenetic females of closely related species in terms of functional morphology. In the genera rich of species such differences sometimes are really minute, and we expect their neutral significance for natural selection. Within several genera of the chydorids, some species have denticles at the posteroventral corner of valve, their number varies and their functional significance is not obvious, but congeneric taxa frequently have no such denticles.

To our minds, numerous cases of convergence in morphological evolution of different body parts in different groups of Cladocera are evidence pro a primary non-adaptive status of such modifications. Each homologous structure demonstrates a wide row of modifications, from full reduction to a hypertrophic development (Smirnov, Kotov, 2009, 2010). Ancestral ovoid general body shape transformed in different groups to globular, laterally compressed and even dorso-ventrally compressed: Graptoleberis Sars, 1862 and Kisakiellus Sousa et ElmoorLoureiro, 2018 (see Alonso, 1996; Sousa, Elmoor-Loureiro, 2018). Advantages of later- ally compressed forms (Acroperus, Camptocercus, Bunops) for living among vegetation remain unclear. But other cladocerans with other body shape live in same conditions, even globular Chydorus spp. (Fig. 7). In contrast to the compressed body, the dorsal median keel known in the majority of Acroperus and Camptocercus species has an obvious adaptive significance, it could be regarded as a structure protecting animals from small-sized predators (Sinev, 2009, 2015).

In non-related genera (belonging to Chydorinae or to Aloninae), the rostrum could be rounded, acute, directed anteriorly or posteriorly, and strongly developed in some extreme cases (Rhynchotalona Norman, 1903 and Rhynchochydorus Smirnov et Timms, 1983). See also our review concerning valves in our previous paper (Smirnov, Kotov, 2009). We see in such cases a "design limitation" (Wake, 1991). Such characters were acquired as a result of morphological radiation and then adjusting to particular environmental requirements in the course of the adaptive radiation of different groups. According to "Kovalevsky"s Law", "colonization of new ecological zones in different groups of organisms is primarily carried out by more primitive members without deep changes in the body plan; only later more advanced forms have a competitive success" (Davitashvili, 1951).

Frequently, when analyzing adaptive changes, the authors concentrate on a particular morphological structure, or few structures, although it is obvious that all morphological structures have evolved as a complex system. It is not obvious that a change of a particular structure will not have a negative effect on other structures. In some cases an adaptive success on a side of living activity is directly sacrificed to success in another side. For example, protective morphology is weakly developed in males as compared to females (Kotov et al., 2009). Success of reproduction is more important than defense from a predator, or success in feeding activity (Kotov, 2013). Other cases of analogous compromises are discussed by Gliwicz (2003). 


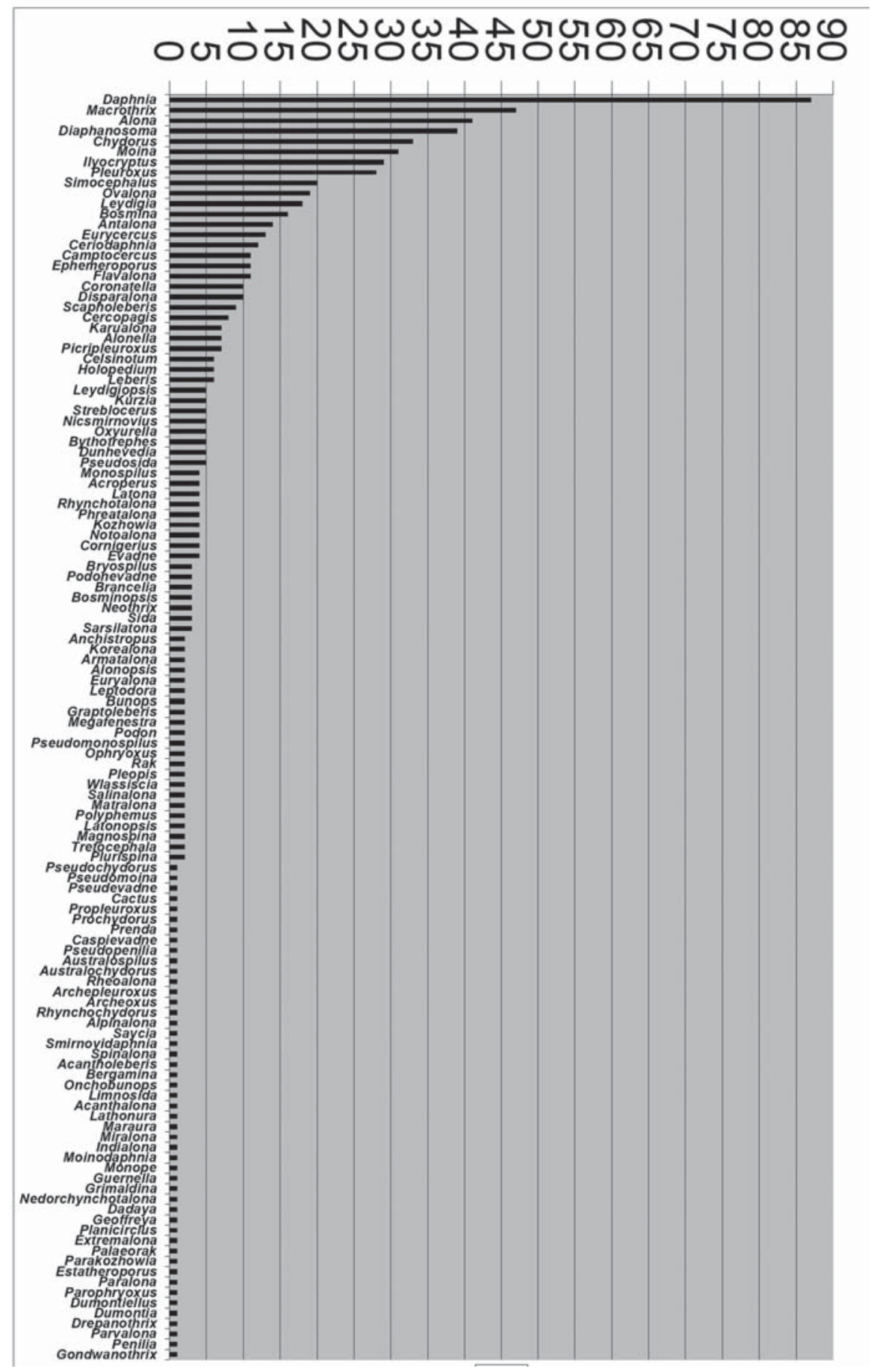

Fig. 6. Number of valid species in each genus of the Cladocera according to personal database of A.A. Kotov (subspecies are not taken into consideration).

Рис. 6. Число валидных видов в каждом роде Cladocera по данным из персональной базы данных А.А. Котова (подвиды не учтены). 

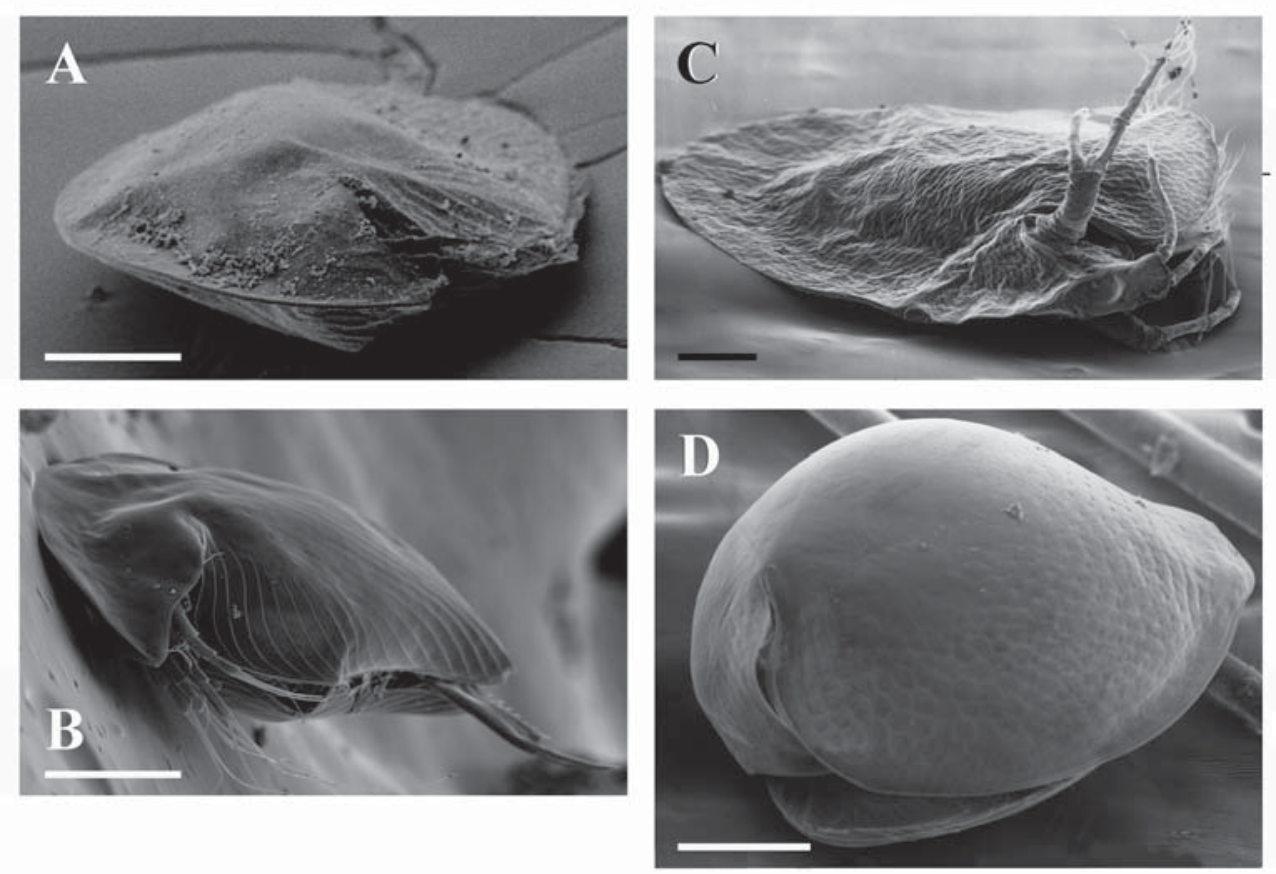

Fig. 7. Anomopod cladocerans inhabited vegetation zone. A - Camptocercus dadayi (Chydoridae: Aloninae); B - Acroperus harpae (Chydoridae: Aloninae); C - Bunops serricaudata (Macrothricidae); Chydorus sphaericus (Chydoridae: Chydorinae). Scale bars $0.1 \mathrm{~mm}$.

Рис. 7. Представители отряда Anomopoda, обитающие в зарослях макрофитов. А - Camptocercus dadayi (Chydoridae: Aloninae); B - Acroperus harpae (Chydoridae: Aloninae); C - Bunops serricaudata (Macrothricidae); Chydorus sphaericus (Chydoridae: Chydorinae). Масштаб: 0,1 мм.

A mutual influence of the thoracic limb structures in the course of their evolutionary modifications is described in detail by Fryer $(1963,1968,1974,1991)$ for different cladoceran groups. It is obvious that before such complicated highly adaptive innovations were supported by natural selection, other modifications, helpful, neutral and even lethal, took place (Meyen, 1988), and many intermediate forms were eliminated. Due to this, all totality of recent forms do not represent a continuum, but clearly subdivided into living forms, and most genera have their remarkably distinct and consummate feeding apparatuses.

We do not have obvious ideas on the phylogenetic relationships within the family Chydoridae, which may have undergone a long evolutionary history (Sacherová, Hebert, 2003). But we can assume that analogous morpholog- ical modifications happened independently in geographically remote regions in non-related (within family) groups. For example, some chydorids have a very long rostrum: Leydigiopsis Sars, 1901, predominantly inhabiting the Neotropics (Van Damme, Sinev, 2013), Rhynchochydorus living in Australia and several species of the genus Disparalona from different continents (Smirnov, Timms, 1983; Sinev, 2004; Neretina et al., 2018). We know that the subfamilies of Chydoridae are old (even potentially of a of mid-Palaeozoic origin, see Sacherová, Hebert, 2003). Apparently a short rostrum is a plesiomorphic state, while the long rostrum is an innovation. We have no ideas on the time of the chydorid genera differentiation (and it is apparently varies among different macrotaxa), but we can assume that (at least in part of the chydorids) the independent elongation of ros- 
trum took place in different continents, and such morphological radiation had a pre-determined vector.

Such regularities are characteristic of evolution of other morphological structures in Cladocera. Moreover, probably forms with globular, ellipsoid, elongated and laterally compressed form were also differentiated in different continents, and in some cases such modifications took place in the alonines, in some cases - in chydorines. Even representatives of extinct Mesozoic order Proanomopoda demonstrate analogies with recent chydorids (for details see Kotov, 2009). But while the former are very successful recently, the latter have gone extinct. Even in some local regions in a continent (i.e. Eurasia) such parallel formation of living forms is possible. One of examples is Baikal lake where endemic alonines with elongated postabdomen appeared: Kozhowia Vasiljeva et Smirnov, 1969 and Parakozhowia Kotov, 2000 (see Vasiljeva, Smirnov, 1969; Kotov, 2000). But we also can not exclude a chance that their long postabdomen is a shared character with other forms, e.g. genus Camptocercus, and Kozhowia and Parakozhowia are relicts survived in Baikal, while their ancestors were replaced in other territories by more advanced species of Camptocercus.

Another region is the Amur basin and surrounding territories, where several non-related taxa with lateral projections on valves were revealed (Kotov, Sinev, 2011; Kotov et al., 2012) (Fig. 8), while their relatives from other regions do not have such characters. This is a "biogeographic style" discussed by Kuzin (1983) and Lyubarsky (1996). The latter has specially discussed a "Sino-Japanese style" in the beetles of the family Cryptophagidae. It is interesting fact that the cladocerans of Far East have also a specific "style" similar to the cryptophagid beetles (Kotov, Sinev, 2011; Kotov et al., 2012).

In conclusion we can say that the cladocerans demonstrate a series of examples on how morphological innovations appeared in the course of morphological radiation, which is initially inadaptive and frequently random ("fruitless" progress in understanding of Kova- levsky (1875)). Also we discussed how morphological innovations then are "adjusted" by adaptive radiation to particular environmental conditions which usually do not exist during the times of the morphological radiation. The progressing morphogenesis was indicated by Fryer (1968: 354) as "incipient specialization". Intermediate forms (initially inadaptive) with a bad combination of characters were probably eliminated. We agree with Rasnitsyn (1987, 2002, $2008)$ that "a stream of general genetic variability is evolutionarily redundant" and that "highly adaptive innovations (new adaptations) do not represent a constant portion of a general stream of variations". But we need to discern between morphological radiation and adaptive radiation as two partly independent phases.

\section{Acknowledgements}

AAK was supported by Russian Government Program of Competitive Growth of Kazan Federal University. SEM works were carried out at the Joint Usage Center "Instrumental Methods in Ecology", A.N. Severtsov Institute of Ecology and Evolution of Russian Academy of Sciences. Thanks to Dr. A.N. Neretina for the assistance in SEM works, Dr. N.M. Korovchinsky, Dr. K. Van Damme and Dr. A.Yu. Sinev for critical comments on earlier draft, Dr. R.J. Shiel for linguistic corrections and Dr Y.R. Galimov for the sample with gynandromorph specimens of D. (Ctenodaphnia) magna.

\section{References}

Adamowicz S.J., Sacherová V. 2006. Testing the directionality of evolution: the case of chydorid crustaceans // J. Evol. Biol. Vol.19. P.1517-1530.

Alonso M. 1996. Crustacea, Branchiopoda. Fauna Iberica 7. Crustacea Branchiopoda. Madrid: Museo Nacional de Ciencias Naturales. Consejo Superior de Investigaciones Científicas. 486 p.

Ax P. 1999. Phyllopodomorpha // Das System der Metazoa II. Ein Lehrbuch der phylogenetischen Systematik. Mainz: G. Fischer. P.156-168.

Belyaeva M., Taylor D.J. 2009. Cryptic species within the Chydorus sphaericus species complex (Crustacea: Cladocera) revealed by molecular markers and sexual stage morphology // Mol. Phyl. Evol. Vol.50. P.534546 . 


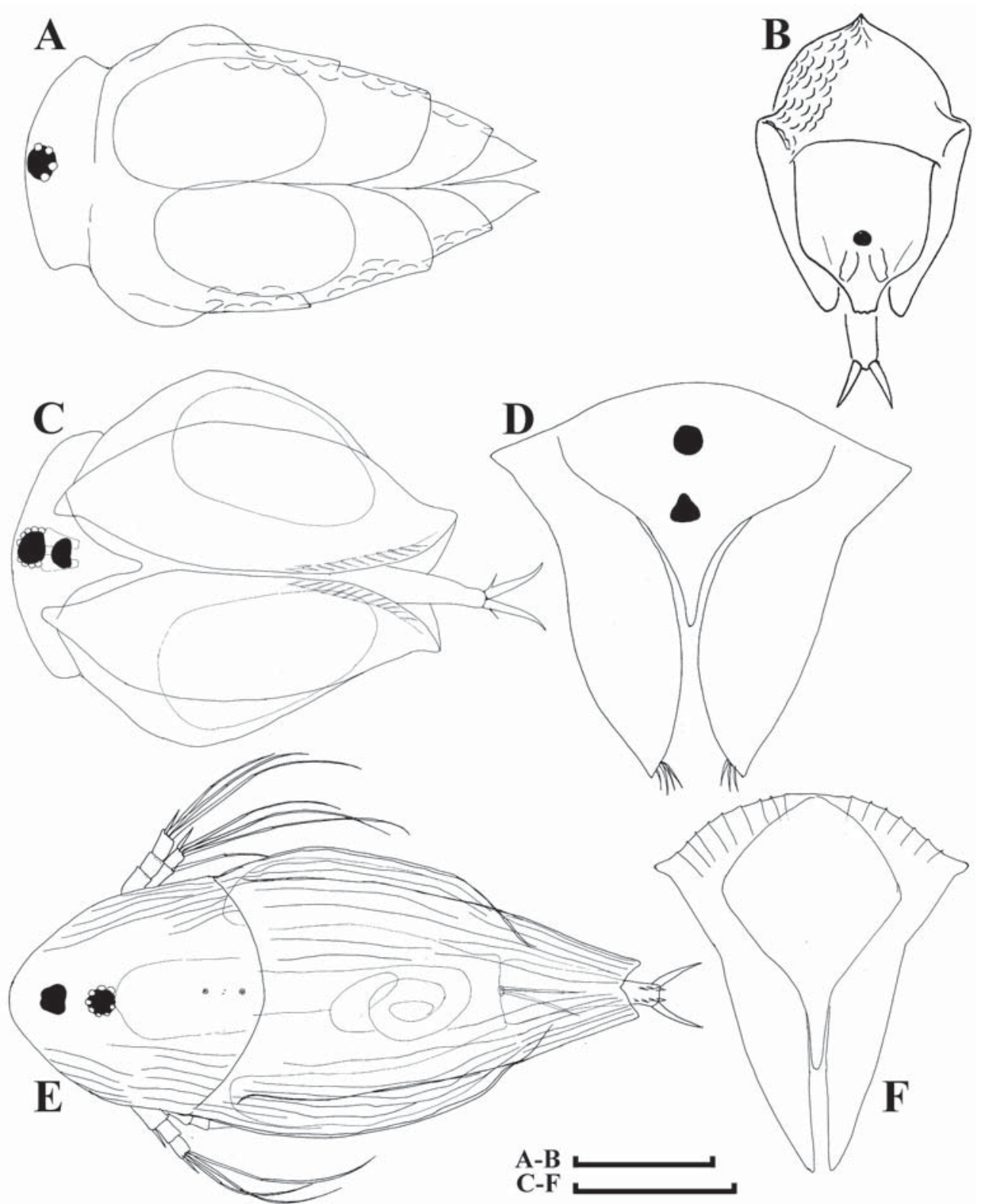

Fig. 8. Representatives of Aloninae $(\mathrm{A}-\mathrm{B})$ and Chydorinae $(\mathrm{C}-\mathrm{F})$ from the Amur basin with lateral projections on valves. A-B - Monospilus daedalus, dorsal and anterior view; C-D - Chydorus irinae, dorsal and anterior view; E-F - Nedorchynchotalona chiangi, dorsal and anterior view. Scale bars $0.1 \mathrm{~mm}$. A, B after Kotov, Sinev, 2011; C-F after Kotov et al., 2012.

Fig. 8. Представители подсемейств Aloninae (A-B) и Chydorinae (C-F) из бассейна Амура, несущие латеральные выросты на створкахs. А-B - Monospilus daedalus, вид со спины и спереди; C-D Chydorus irinae, вид со спины и спереди; Е-F - Nedorchynchotalona chiangi, вид со спины и спереди. Масштаб: 0,1 мм. А, В по: Kotov, Sinev, 2011; C-F по: Kotov et al., 2012. 
Charlesworth B., Lande R. 1982. Morphological stasis and developmental constraint: no problem for Neo-Darwinism // Nature. Vol.296. P.610-610.

Cooper R.A., Maxwell P.A., Crampton J.S., Beu A.G., Jones C.M., Marshall B.A. 2006. Completeness of the fossil record: Estimating losses due to small body size // Geology. Vol.34. P.241-244.

Davitashvili L.S. 1951. [V.O. Kovalevskiy. 2nd Edition]. Moscow: Acad. Sci. USSR Publ. 584 p. [In Russian].

Dogiel V.A. 1954. [Oligomerization of the homologous organs as one of the main paths in animal evolution]. Leningrad: Leningrad University Press. 368 p. [In Russian]

Dumont H.J., Negrea S.V. 2002. Introduction to the class Branchiopoda // H.J. Dumont (ed.). Guides to the identification of the microinvertebrates of the continental waters of the world. Vol.19. Leiden: Backhuys Publ. 398 p.

Eldredge N., Gould S.J. 1972. Punctuated equilibria: an alternative to phyletic gradualism // T.J.M. Schopf (ed.). Models in Paleobiology. San Francisco: Freeman, Cooper and Company. P.82-115.

Faustová M., Sacherová V., Sheets H.D., Svensson J.E., Taylor D.J. 2010. Coexisting cyclic parthenogens comprise a Holocene species flock in Eubosmina // PLOS ONE. Vol.5. No.7. e11623.

Faustová M., Sacherová V., Svensson J.-E., Taylor D.J. 2011. Radiation of European Eubosmina (Cladocera) from Bosmina (E.) longispina - concordance of multipopulation molecular data with paleolimnology // Limnol. Oceanogr. Vol.56. P.440-450.

Frey D.G. 1976. Interpretation of Quaternary palaeoecology from Cladocera and midges, and prognosis regarding usability of other organisms // Can. J. Zool. Vol.54. P.2208-2226.

Frey D.G. 1982. Questions concerning cosmopolitanism in Cladocera // Arch. Hydrobiol. Bd.93. S.484-502.

Frey D.G. 1987. The taxonomy and biogeography of the Cladocera // Hydrobiologia. Vol.145. P.5-17.

Frey D.G. 1988. Separation of Pleuroxus laevis Sars, 1861 from two species in North America: Pleuroxus straminius Birge, 1879 and Pleuroxus chiangi n. sp. (Cladocera, Chydoridae) // Can. J. Zool. Vol.66. P.2534-2563.

Fryer G. 1963. The functional morphology and the feeding mechanism of the chydorid cladoceran Eurycercus lamellatus (O. F. Müller) // Trans. Roy. Soc. Edinburgh. Vol.65. P.335-381.

Fryer G. 1968. Evolution and adaptive radiation in the Chydoridae (Crustacea: Cladocera): a study in comparative functional morphology and ecology // Phil. Trans. Roy. Soc. London. Ser.B. Vol.254. P.221385.

Fryer G. 1974. Evolution and adaptive radiation in the Macrothricidae (Crustacea, Cladocera): a study in comparative functional morphology and ecology // Phil. Trans. Roy. Soc. London. Ser.B. Vol.269. P.137274.

Fryer G. 1976. Adaptation, speciation and time // Zool. Scr. Vol.5. P.171-172.
Fryer G. 1991. Functional morphology and the adaptive radiation of the Daphniidae (Branchiopoda: Anomopoda) // Phil. Trans. Roy. Soc. London. Ser.B. Vol.331. P.1-99.

Fryer G. 1995. Phylogeny and adaptive radiation within the Anomopoda: a preliminary exploration // Hydrobiologia. Vol.307. P.57-68.

Fryer G. 1997. Case 2990. Disparalona Fryer, 1968 (Crustacea, Branchiopoda): proposed conservation // Bull. Zool. Nomencl. Vol.54. No.2. P.89-91.

Galimov Y., Walser B., Haag C.R. 2011. Frequency and inheritance of non-male producing clones in Daphnia magna: evolution towards sex specialization in a cyclical parthenogen? // J. Evol. Biol. Vol.24. P.1572-1583.

Glagolev S.M., 1986. [Morphology, systematics and geographic distribution of the cladoceran genus Daphnia from Eurasia]. Ph.D. Thesis. Moscow: IEMEZh AN SSSR. 226 p. [In Russian]

Gliwicz Z.M. 2003. Between hazards of starvation and risk of predation: the ecology of offshore animals // Exell. Ecol. Vol.12. P.1-379.

Goldschmidt R. 1982. The material basis of evolution. New Haven: Yale Univ. Press. 436 p.

Gould S.J., Eldredge N. 1977. Punctuated equilibria: the tempo and mode of evolution reconsidered // Paleobiology. Vol.3. P.115-151.

Hegna T.A., Kotov A.A. 2016. Ephippia belonging to Ceriodaphnia Dana, 1853 (Cladocera: Anomopoda: Daphniidae) from the Lower Cretaceous of Australia // Palaeontol. Electron. Vol.19.3.40A. P.1-9.

Kerfoot W.C., Lynch M. 1987. Branchiopod communities: associations with planktivorous fish in space and time // W.C. Kerfoot, A. Sih (eds.). Predation. Direct and indirect impacts on aquatic communities. Hanover and London: Academic Press. P.367-378.

Korovchinsky N.M. 1990. Evolutionary morphological development of the Cladocera of the superfamily Sidoidea and life strategies of crustaceans of continental waters // Int. Rev. ges. Hydrobiol. Hydrograp. Vol.75. P.649-676.

Korovchinsky N.M. 2004. [Cladocerans of the order Ctenopoda of the world fauna (morphology, systematics, ecology, biogeography)]. Moscow: KMK Press. 410 p. [In Russian]

Korovchinsky N.M. 2006. The Cladocera (Crustacea: Branchiopoda) as a relict group // Zool. J. Linn. Soc. Vol.147. P.109-124.

Kotov A.A. 2000. Analysis of Kozhowia Vasiljeva \& Smirnov, 1969 (Chydoridae, Anomopoda, Branchiopoda), and a description of Parakozhowia n. gen. // Hydrobiologia. Vol.437. P.17-56.

Kotov A.A. 2007. Jurassic Cladocera (Crustacea, Branchiopoda) with a description of an extinct Mesozoic order // J. Nat. Hist. Vol.41. P.13-37.

Kotov A.A. 2009. A revision of the extinct Mesozoic family Prochydoridae Smirnov, 1992 (Branchiopoda: Cladocera) with a discussion of its phylogenetic position // Zool. J. Linn. Soc. Vol.155. P.253-265.

Kotov A.A., Jeong H.J., Lee W. 2012. Cladocera (Crustacea: Branchiopoda) of the south-east of the Korean 
Peninsula, with twenty new records for Korea // Zootaxa. Vol.3368. P.50-90.

Kotov A.A., Ishida S., Taylor D.J. 2009. Revision of the genus Bosmina Baird, 1845 (Cladocera: Bosminidae), based on evidence from male morphological characters and molecular phylogenies // Zool. J. Linn. Soc. Vol.156. P.1-56.

Kotov A.A., Korovchinsky N.M. 2006. First record of fossil Mesozoic Ctenopoda (Crustacea, Cladocera) // Zool. J. Linn. Soc. Vol.146. P.269-274.

Kotov A.A., Sinev A.Yu. 2011. Cladocera (Crustacea, Branchiopoda) of the Zeya basin (Amurskaya Area, Russian Federation). 2. Descriptions of new taxa // Zool. Zhurn. Vol.90. P.272-284.

Kotov A.A., Taylor D.J. 2011. Mesozoic fossils (>145 Mya) suggest the antiquity of the subgenera of Daphnia and their coevolution with chaoborid predators // BMC Evol. Biol. Vol.11. No.129.

Kovalevsky V.O. 1875. [Osteology of two fossil species of Undulata] // Izv. Obshch. Lubit. Estestv. Antrop. Etnogr. Vol.16. No.1. P.1-59 [in Russian].

Krassilov V.A. 1986. [Unsolved Problems of Evolutionary Theory]. Vladivostok: Dal'nauka. 147 p. [In Russian]

Kuzin B.S. 1983. [Problems of systematics and classification in the correspondence of A.A. Lyubischew and B.S. Kuzin (based on archive materials of A.A. Lyubischew in Leningrad section of Archive of USSR, stock № 1033, inventory № 3)] // Teoriya i metodologiya biologicheskikh klassifikatsiy [Theory and methodology of biological classifications]. Moscow: Nauka. P.141-167 [in Russian].

Lampert W. 2011. Daphnia: development of a model organism in ecology and evolution // Excell. Ecol. Vol.21. P.1-250.

Lehman N., Pfrender M.E., Morin P.A., Crease T.J., Lynch M. 1995. A hierarchical molecular phylogeny within the genus Daphnia // Mol. Phyl. Evol. Vol.4. P.395407.

Longhurst A.R. 1955. Evolution in the Notostraca // Evolution. Vol.9. P.84-86.

Lyubarsky G.Yu. 1996. [Archetype. style and rank in biological systematics] // Sbornik Trud. Zool. Mus. MGU. Moscow. Vol.35. P.1-434 [in Russian].

Mathers T.C., Hammond R.L., Jenner R.A., Hänfling B., Gómez A. 2013. Multiple global radiations in tadpole shrimps challenge the concept of 'living fossils' // PeerJ. Vol.1. No.e62.

Meyen S.V. 1987. [Fundamentals of Palaeobotany]. Moscow: Nedra. 403 p. [In Russian]

Meyen S.V. 1988. [Problems of phylogenetic classification of organisms] // Sovremennaya Paleontologiya. Vol.1. P.497-511 [in Russian].

Neretina A.N., Garibian P.G., Sinev A.Yu., Kotov A.A. 2018. Diversity of the subgenus Disparalona (Mixopleuroxus) Hudec, 2010 (Crustacea: Cladocera) in the New and Old World // J. Nat. Hist. Vol.52. P.155-205.

Osborn H.F. 1902. The law of adaptive radiation // Amer. Nat. Vol.36. P.353-363.

Ponomarenko A.G. 2012. [Earlier stages of the ecosystems of continental water bodies evolution] // S.V. Rozh- nov (ed.). Rannyaya kolonizatsiya sushi [Earlier colonization of land]. Moscow: Paleontological Institute. P.92-119 [in Russian].

Popov I.Yu. 2000. El problema de los monstruos en la evolución // Ludus vitalis. Vol.7. No.13. P.35-50.

Popova E.V., Petrusek A., Kořínek V., Mergeay J., Bekker E.I., Galimov Y.R., Neretina T.V., Taylor D.J., Kotov A.A. 2016. Revision of the Old World Daphnia (Ctenodaphnia) similis group (Cladocera: Daphniidae) // Zootaxa. Vol.4161. P.1-40.

Rasnitsyn A.P. 1987. [Tempo of evolution and evolutionary theory (hypothesis of the adaptive compromise)] // L.R. Tatarinov, A.P. Rasnitsyn (eds.). Evolyutsiya i biotsenoticheskie krizisy [Evolution and Biocenotic Crises]. Moscow: Nauka. P.46-64 [in Russian].

Rasnitsyn A.P. 2002. [Evolutionary process and methodology of systematics] // Tr. Russ. Entomol. Obsh. Vol.73. P.1-107 [in Russian].

Rasnitsyn A.P. 2008. [Theoretical basics of evolutionary biology] // Zherikhin V.V., Ponomarenko A.G., Rasnitsyn A.P. Vvedenie v paleoentomologiyu [Introduction to Palaeoentomology]. Moscow: KMK Scientific Press. P.6-79 [in Russian].

Reisser C.M.O., Fasel D., Hürlimann E., Dukiè M., HaagLiautard C., Thuillier V., Galimov Y., Haag C.R. 2017. Transition from environmental to partial genetic sex determination in Daphnia through the evolution of a female-determining incipient W chromosome // Mol. Biol. Evol. Vol.34. P.575-588.

Sacherová V., Hebert P.D.N. 2003. The evolutionary history of the Chydoridae (Crustacea: Cladocera) // Biol. J. Linn. Soc. Vol.79. P.629-643.

Sinev A.Yu. 2004. Redescription of two species of the genus Leydigiopsis Sars, 1901 (Branchiopoda, Anomopoda, Chydoridae) // Invert. Zool. Vol.1. No.1. P.75-92.

Sinev A.Yu. 2009. Discrimination between two sibling species of Acroperus (Baird, 1843) from the Palearctic (Cladocera: Anomopoda: Chydoridae) // Zootaxa. Vol.2176. P.1-21.

Sinev A.Yu. 2015. Morphology and phylogenetic position of three species of genus Camptocercus Baird, 1843 (Cladocera: Anomopoda: Chydoridae)//Zootaxa. Vol. 4040. P. 169-186.

Sinev A.Yu. 2017. [Morphology, systematics and zoogeography of the cladocerans of subfamily Aloninae (Cladocera: Anomopoda: Chydoridae)]. Dr.Sci. Thesis. Moscow: Biological Faculty of M.V. Lomonosov Moscow State University. 428 p. [In Russian]

Smirnov N.N. 1968. On comparative functional morphology of limbs of Chydoridae (Cladocera) // Crustaceana. Vol.14. P.76-96.

Smirnov N.N. 1969. Morpho-functional grounds of the mode of life of Cladocera. III. Oligomerization in Cladocera // Hydrobiologia. Vol.34. P.235-242.

Smirnov N.N. 1971. [Chydoridae of the world fauna] // Fauna SSSR. Rakoobraznie. Vol.1. No.2. P.1-531 [in Russian].

Smirnov N.N. 1992. Mesozoic Anomopoda (Crustacea) from Mongolia // Zool. J. Linn. Soc. Vol.104. P.97116. 
Smirnov N.N. 1999. Morpho-functional grounds of life mode of "Cladocera". X. Specializaed "Cladocera" (Phyllopoda: Crustacea) as victims of morphological radiation // Arthropoda Selecta. Vol.8. No.1. P.3541.

Smirnov N.N. 2004. First record of Pleuroxus pigroides in Russia // Arthropoda Selecta. Vol.13. No.3. P.109112.

Smirnov N.N. 2010. [Historic ecology of lake zoocenoses]. Moscow: KMK Sci. Press. 225 p. [In Russian]

Smirnov N.N. 2017. Physiology of the Cladocera. 2nd Edition. London: Academic Press. 418 p.

Smirnov N.N., Kotov A.A. 2009. Morphological radiation with reference to the carapace valves of the Anomopoda (Crustacea: Cladocera) // Int. Rev. Hydrobiol. Vol.94. P.580-594.

Smirnov N.N., Kotov A.A. 2010. The morphological radiation of setae of the Cladocera (Crustacea) and their potential for morphogenesis // Int. Rev. Hydrobiol. Vol.95. P.482-519.

Smirnov N.N., Kotov A.A., Coronel J. 2006. Partial revision of the aduncus-like species of Pleuroxus Baird, 1843 (Chydoridae, Cladocera) from the southern hemisphere with comments of subgeneric differentiation within the genus // J. Nat. Hist. Vol.40. P.1617-1639.

Smirnov N.N., Timms B.V. 1983. A revision of the Australian Cladocera (Crustacea) // Rec. Austral. Mus. Suppl. Vol.1. P.1-132.

Sousa F.D.R., Elmoor-Loureiro L.M.A. 2018. Cladocera from the Upper Xingu River Basin with the description of a new genus of the Chydoridae (Crustacea: Branchiopoda: Anomopoda) // Zootaxa. Vol.4418. P.545-561.

Sturmbauer C., Meyer A. 1992. Genetic divergence, speciation and morphological stasis in a lineage of African cichlid fishes // Nature. Vol.358. P.578.

Takhtajan A.L. 1983 [Macroevolutionary processes in the history of plant world] // Bot. Zhurn. Vol.68. P.15931603 [in Russian].

Tasch P. 1969. Branchiopoda // R.C. Moore (ed.). Treatise of Invertebrate Paleontology. Part R. Arthropoda.
Vol.4. No.1. Boulder, Colorado: Geological Society of America; Lawrence, Kansas: University of Kansas Press. P.128-191.

Trusheim F. 1938. Triopsiden (Crust. Phyll.) aus dem Keuper Frankens // Palaeontol. Zeitsch. Bd.19. S.198216.

Van Damme K. 2010. A revision of the genus Alona Baird, 1843 (Crustacea: Branchiopoda: Anomopoda). Ph.D. Thesis. Ghent: The Sate University of Ghent. 506 p.

Van Damme K., Dumont H. 2006. Sex in a cyclical parthenogen: mating behaviour of Chydorus sphaericus (Crustacea; Branchiopoda; Anomopoda) // Fresh. Biol. Vol.51. P.2334-2346.

Van Damme K., Elías-Gutiérrez M., Dumont H.J. 2011. Three rare European "Alona" taxa (Branchiopoda: Cladocera: Chydoridae), with notes on distribution and taxonomy // Anns. Limnol. Vol.47. P.45-63.

Van Damme K., Kotov A.A. 2016. The fossil record of the Cladocera (Crustacea: Branchiopoda): Evidence and hypotheses // Earth-Sci. Rev. Vol.163. P.162-189.

Van Damme K., Kotov A.A., Dumont H.J. 2010. A checklist of names in Alona Baird 1843 (Crustacea: Cladocera: Chydoridae) and their current status: an analysis of the taxonomy of a lump genus // Zootaxa. Vol.2330. P.1-63.

Vasiljeva G.L., Smirnov N.N. 1969. [Chydoridae (Cladocera) of Lake Baikal] // Zool. Zhurn. Vol.48. P.184196 [in Russian].

Wagner P., Haug J.T., Sell J., Haug C. 2017. Ontogenetic sequence comparison of extant and fossil tadpole shrimps: no support for the "living fossil" concept // PalZ. Vol.91. P.463-472.

Wake D.B. 1991. Homoplasy: the result of natural selection, or evidence of design limitations? // Amer. Nat. Vol.138. P.543-567.

Woltereck R. 1920. Variation und Artbildung. Analitische und experimentelle Untersuchungen an pelagischen Daphniden und anderen Cladoceren // Int. Rev. ges. Hydrobiol. Bd.9. S.1-151.

Zherikhin V.V. 2003. [Selected works on palaeoentomology and phytocoenology]. Moscow: KMK Sci. Press. 542 pp. [In Russian]

Responsible editor K.G. Mikhailov 